\title{
Flesh quality in large rainbow trout with high or low fillet yield
}

\author{
Jerôme Bugeon ${ }^{1,{ }^{*}}$, Florence Lefevre ${ }^{1}$, Mireille Cardinal ${ }^{2}$, Ayhan Uyanik ${ }^{1}$, Armel Davenel $^{3}$, Pierrick \\ Haffray $^{4}$
}

${ }^{1}$ INRA, UR1037, SCRIBE, IFR140 Ouest-Genopole, F-35000 Rennes, France

${ }^{2}$ IFREMER, STAM, F-44300 Nantes, France

${ }^{3}$ CEMAGREF, UR TERE, F-35044 Rennes, France

${ }^{4}$ SYSAAF, F-35000 Rennes, France

*: Corresponding author : J. Bugeon, TEL: 33223485010; FAX: 33223485020; email address : jerome.bugeon@rennes.inra.fr

\begin{abstract}
:
Rainbow trout with different fillet yield [56 and 65\% for low (LY) and high yield (HY), respectively] were examined for muscle organization and flesh quality (instrumental and sensorial evaluations). Both groups had similar body weight (3.6 kg in mean), but the HY group had a higher carcass yield $(+15 \%)$. Higher total muscle area in the HY group $(+20 \%)$ was associated with a higher number of muscle fibers (+22\%). Flesh of the HY group presented a higher area of myosepta $(+10 \%)$, fat content $(+10 \%)$ and luminosity $(+6 \%)$. Raw fillet mechanical resistance was higher for the HY group; an opposite result was obtained for cooked flesh. Sensorial evaluation of cooked flesh revealed no important differences between groups. Smoked fillet from the HY group presented higher area of white stria and lower flesh color intensity. To conclude, higher muscle mass content had no negative consequences on flesh quality in rainbow trout.
\end{abstract}

\section{Practical applications:}

Farmed rainbow trout present great variability in fillet yield and low fillet yield is considered as an unexpected carcass quality trait, as it leads to financial loss and higher volume of off-products, difficult to valorise. So, the improvement of fillet yield appears as an interesting criterion for genetic selection but only if increasing fillet yield does not result in a lower quality product. So, this study provides useful information on the characteristics of the flesh of rainbow trout with different fillet yield. The results reported in this paper show to fish farmers and processors that improving fillet yield has no negative impact on raw and processed flesh quality. From an academic point of view, this work provides additional knowledge in the area of the determinism of flesh quality in farmed fish.

Keywords: Fish; muscle; fillet yield; flesh quality; texture; salmonids. 


\section{Introduction}

Fish fillet, as the main edible portion of fish, hold the main economic and nutritional interest of fish production. Increasing fillet yield, without any negative effect on flesh quality, is a major challenge for fish farmers. Even small differences in yields have a considerable economic impact for fish processing companies (Rora et al. 2001) as the fillet constitutes the most valuable part of the product. For example, for the French trout production the price of the fillet is treble the price of the whole fish (unpublished data from an economic survey of the French "Comité Interprofessionnel des Produits de l'Aquaculture"), so an increase of 5 units of fillet yield corresponds to an increase of $15 \%$ in terms of added value.

During fish processing for fillet production the main wastes are viscera (and associated perivisceral fat), head, skeleton, skin, fins and subcutaneous adipose tissue. Finally, in rainbow trout, the edible part represents frequently less than half of the fish live weight. Great variability in fillet yield for different farms and within farms was reported (Rora et al. 2001). For example measurements on 425 Atlantic salmon (Salmo salar) show that loss due to filleting and trimming ranged from 30 to $45 \%$ (38\% on average) (Morkore et al. 2001). Numerous factors can affect salmonids fillet yield such as fish size, feed ration (Einen et al. 1998; Einen et al. 1999), diet composition (Rasmussen 2001), genetic line (Smith et al. 1988), or sexual maturation (Paaver et al. 2004). Thus, contrary to fisheries, fish farming, as other livestock productions, has the opportunity to control some characteristics of the animal. The possible improvement of fillet yield by genetic selection was recently demonstrated in rainbow trout (Kause et al. 2007).

Fish fillet is organized in myomeres, consisting mainly of muscle fibres, connective and adipose tissues (Dunajski 1979). Fish with high fillet yield present higher muscle mass compared to fish with low fillet yield. This higher muscle mass is achieved all along the fish growth by the combined development of all muscle tissues (Fauconneau et al. 1995). For land species, the post-natal muscle growth is achieved by hypertrophy (increase in size) of existing muscle cell. In fish, the increase in muscle mass was obtained all along the post-natal growth phase, both by hyperplasia (increase in muscle cell number) and hypertrophy. As fibre maximal diameter is limited by diffusion of oxygen in muscle fibre (Johnston et al. 2004), the recruitment of new muscle fibres is essential to explain growth differences between fish species, consequently fish species presenting higher overall growth exhibit a higher rate of hyperplasia (Weatherley et al. 1988). For land species, different animal models presenting higher muscle mass are available, such as callipyge sheep, double muscle cattle or chicken and pig lines (Rehfeldt et al. 2000). On these land species models, the increase in muscle mass was obtained either by hypertrophy, for example on callipyge sheep (Carpenter et al. 1996) or chicken line with high muscle breast yield (Guernec et al. 2003), or by hyperplasia only during the embryonic period for double muscle cattle (Rehfeldt et al. 2000). In fish, strains of salmon or trout presenting higher overall growth also exhibit higher muscle growth (Johnston et al. 2000b; Valente et al. 1999), but no genetic models of fish with high or low muscle mass is available. To our knowledge, for fish, there is no data (phenotypic or genetic) available, comparing the relationship between muscle cellularity and the proportion of muscle mass in animals exhibiting similar overall body growth.

Flesh quality is the main concern for consumers, amongst which, fat content, colour, texture and flavor are the main qualities sought after (Rasmussen 2001). These features depend partly on muscle characteristics in terms of composition and tissue organization. For example, raw flesh texture depends upon collagen content and its crosslink (Hatae et al. 1986; Li et al. 2005). Muscle cellularity could influence flesh texture, as an inverse relationship was obtained between muscle fibre diameter and mechanical resistance of the raw flesh and sensory firmness of the smoked flesh (Bugeon et al. 2003; Johnston et al. 2000a). In the cooked flesh, the connective tissue is less important due to its low 
thermal stability, but muscle fibre size also has a significant influence: fish species with a lower mean fibre diameter present firmer cooked flesh than fish species with bigger muscle fibre (Hurling et al. 1996).

Many studies on fish related the effect of the fish rearing condition on fillet yield and flesh quality. To our knowledge, no data is reported for the consequences of different muscle mass on fish flesh quality within the same species. For land species, for example, the meat fat content of animals presenting a higher muscle mass was lower than for animals with "normal" muscle mass (Hocquette et al. 2000). However, the impact of greater muscle growth on other quality parameters like meat texture depends largely upon the animal model and no general relationship between muscle fibre size and meat quality was demonstrated (Rehfeldt et al. 2000).

We hypothesised that, in rainbow trout, different proportion in muscle mass could be associated to different flesh quality. So, the aim of the present study was to characterize muscle growth and to compare flesh quality (measured instrumentally and with a sensory panel) in two groups of rainbow trout, one with low and the other with high fillet yield.

\section{Materials and methods}

\subsubsection{Fish}

All female triploid rainbow trout (Oncorhynchus mykiss) were reared for 25 months in a freshwater commercial fish farm and fed with a commercial diet (Biomar Eco 72). One thousand and five hundred fishes were starved for 5 days and then slaughtered by carbon dioxide stunning followed by exsanguination through gill cutting in a fish processing factory. Fish with external deformations were discarded, the remaining fish were sorted and sampled, based on their raw fillet yield (raw fillet included skin and subcutaneous fat), 25 fish with a low (mean of $56 \pm 3.2 \%$ ) and 25 fish with a high (mean of $65 \pm 1.4 \%$ ) raw fillet yield were distributed in a Low (LY) and High Yield (HY) group respectively. For each group, fifteen trout were analysed for instrumental quality assessment, and ten trout were submitted to sensory analysis.

\subsubsection{Morphometric measurements, sampling and sample treatment}

All measurements and sampling were done after death, on fish in a pre-rigor state. The following morphometric traits were measured: body weight (BW), body length (L), Viscera weight $(\mathrm{VW})$, carcass weight $(\mathrm{CW})$ and fillet (skinned and trimmed) weight (FW). The following parameters were calculated: condition factor $\left(\mathrm{K}=\mathrm{BW} / \mathrm{L}^{3} \times 10^{5}\right)$, viscero-somatic index $(\mathrm{VSI}=\mathrm{VW} / \mathrm{BW})$, carcass yield $(=\mathrm{CW} / \mathrm{BW})$, fillet yield $(=\mathrm{FW} / \mathrm{BW})$. Muscle samples were taken for histological analysis from the left side of fish, just beneath the dorsal fin in the dorsal mid part of the white muscle. For each fish, one fillet per fish was taken on prerigor fish, packed in a plastic bag and kept in ice for 2 days, prior to quality analysis. One half-cutlet was sampled on the other fillet in front of the dorsal fin for colour image analysis and packed in a plastic bag and kept in ice for 2 days.

\subsubsection{Flesh quality instrumental assessment}

Lipid and $\mathrm{pH}$ analysis

Flesh $\mathrm{pH}$ was measured at $48 \mathrm{~h}$ post mortem in the anterior part of the fillet (Figure 1), after homogenisation of $5 \mathrm{~g}$ of muscle in 4 volumes of distilled water. Lipid content was estimated in the Norwegian Quality Cut (NQC) of the fillet using NMR technology as previously described (Toussaint et al. 2002). 


\section{Cutlet color image analysis}

Digital picture of one cutlet (half side) sampled in front of the dorsal fin was analyzed as described by Marty-Mahe et al (Marty-Mahe et al. 2004) with some modifications for the analysis on half side cutlets. The color image segmentation methods allow quantifying quality traits such as area of peripheral fat, muscle tissues and myosepta.

Fillet color

Fillet color was assessed using a portable Minolta Chromameter CR-200 (Minolta, France) equipped with light source $C$ and a $2^{\circ}$ observer angle, calibrated to a white standard. For each fillet, three measurements were done on the interior part of the fillet, one between the front of the fillet and the dorsal fin, one under the dorsal fin and the last one above the anal fin (Figure 1). The mean of these three measurements values was calculated. Data were expressed in $L^{*}, a^{*}, b^{*}$ system, representing luminosity, redness, and yellowness, respectively, as recommended by CIE (CIE 1976).

\section{Mechanical resistance measurements}

Mechanical resistance was measured in the laboratory $48 \mathrm{~h}$ after fish death on the raw post-rigor fillet and $96 \mathrm{~h}$ post mortem for the cooked fillet. Fillet were, cooked at $48 \mathrm{~h}$ post mortem in a $400 \mathrm{~W}$ micro wave oven during a time adjusted depending on sample weight to reach $65^{\circ} \mathrm{C}$, and stored at $4^{\circ} \mathrm{C}$. Samples from the anterior and the caudal part of the fillet (Figure 1) were analysed using a Kramer shear cell mounted on an INSTRON universal testing machine equipped with a $2 \mathrm{kN}$ load cell (Instron 5544). Specific resistance was calculated as the maximal force divided by the weight of the sample (Szczesniack et al. 1970).

\subsubsection{Quantitative histology}

Muscle samples were fixed in Carnoy fixative (absolute ethanol, chloroform, acetic acid, 6:3:1) for $24 \mathrm{~h}$ at $4^{\circ} \mathrm{C}$, dehydrated in $95^{\circ}$ alcohol and alcohol/butanol (50/50) embedded in paraffin. Transverse muscle sections $(10 \mu \mathrm{m})$ were cut using a microtome (Microm HM 355 ) and stained with Sirius Red and Fast Green 0.1\% in saturated picric acid (Lopez-DeLeon and Rojkind 1985). Areas of individual muscle fibres (300 to 500 fibres per fish) were measured using Visilog 5.4 for Windows. As histological treatments including paraffin embedding lead to muscle fiber shrinkage, individual muscle fiber area was multiply by a shrinkage correction (SC) factor calculated as follow : SC = (total image area -connective tissue area) / (fiber total area). Muscle fibre diameters (D) were then calculated using the formula $D=2 \sqrt{ }($ area/ $\pi)$ under the assumption that individual fibre cross-sections were circular. The white muscle fibre number per myotome was estimated using the total number of fibres per histological section and the area of the white muscle part (without the adipose tissue) of the cutlets measured with the colour image analysis method described above.

\subsubsection{Sensory evaluation of cooked and smoked fillets}

Conventional profiling tests were carried out to characterize the sensory properties of the cooked and smoked trout flesh. Ten fillets from HY and LY groups were individually packed in plastic bag and transported in ice to the laboratory for analysis. Once the fillets were rinsed with tap water $\left(15^{\circ} \mathrm{C}\right)$, the right-side fillets were covered with a plastic film to avoid any drying of the flesh surface and kept one day at $+4^{\circ} \mathrm{C}$ before being cooked for the sensory test. The left-side fillets were hand-salted with refined salt (Salins du Midi, France) for two hours at $10^{\circ} \mathrm{C}$, rinsed on grids with tap water, then stored in a cold room at 
$+4^{\circ} \mathrm{C}$ for $18 \mathrm{hrs}$ until smoking. Fillets were smoked in an HMI Thirode (PC90 Model) smokehouse, equipped with a generator (Thirode, France) producing smoke by pyrolysis (between 400 and $450{ }^{\circ} \mathrm{C}$ ) of beech sawdust. The smoke swept the fillets for 2 hours at a temperature of $22^{\circ} \mathrm{C}$. The fillets were weighted before and after the salting and smoking process to estimate the processing yields. The next day, fillets were cut in portions for sensory evaluation and chemical analysis, vacuum packed and stored for one week at $+4^{\circ} \mathrm{C}$. Sensory evaluation was performed on the central part of the fillet.

Two sensory sessions were organised, one for cooked products and one for smoked products. Products, assigned 3-digit numbers and randomised for the order of presentation were presented simultaneously at each session. Each panellist received two cutlets of $3 \mathrm{~cm}$ width from the two groups (HY and LY) cooked in a closed glass bowl in a microwave $(600 \mathrm{~W})$ for 2 minutes or two cutlets of $1 \mathrm{~cm}$ width of smoked samples. Samples were scored by a pool of twenty-four panellists belonging to the IFREMER staff, already trained on sensory descriptors for cooked and smoked fishes. The descriptors, relating to the odour, appearance, flavour and texture are described in table 1 . Sessions were performed in individual partitioned booths according to recommendations of NF V09-105 (1995), equipped with a computerised system (Fizz system, Biosystèmes, Dijon). Panellists rated the sensory attributes on a continuous scale, from low intensity (0) to high intensity (10).

\subsubsection{Statistical analysis}

A one-way analysis of variance was used to analyse the difference between the HY and LY groups on all instrumental measurements using Statistica for Windows (version 5.1). Multifactor analyses of variance were carried out on sensory data with Statgraphics Plus 5.0 software (Sigma Plus, Paris, France). These analyses included the factors "yield group" and "panellist". The significant statistical level was set at $p<0.05$.

\section{Results}

\subsubsection{Fish characteristics}

Fish from both groups had similar body weight but the body length of the LY group was lower than that of the HY. Thus the LY group present significant higher condition factor $\mathrm{K}$ $(p<0.001)$, and so a more "compact" body morphology (Table 2). The VSI was significantly greater in the LY than in the HY group $(p<0.001)$. The carcass yield was significantly lower $(-13 \%)$ in the LY group than in the HY group $(p<0.001)$. The fillet yield (mean of both groups) was $61 \%$ and $41 \%$ for the untrimmed and trimmed fillet respectively. The fillet yield (trimmed and skinned fillet) was significantly lower $(-17 \%)$ for the LY group than for the HY group $(p<0.001)$.

\subsubsection{Muscle characteristics}

Colour image analysis showed that total cutlet area was significantly higher $(+20 \%)$ for the HY group compared to the LY group $(p<0.001)$. The adipose tissue (including both dorsal and ventral subcutaneous fat and red muscle) area was significantly higher $(p<0.01)$ for the HY group compared to the LY group but the proportion of adipose tissue was similar between the two groups. The proportion of the myosepta was significantly $(p<0.01)$ higher $(+10 \%)$ for the HY group than for the LY group (Table 3). 


\subsubsection{Quantitative histology}

Quantitative histology analysis revealed that the mean white muscle fibre diameter was similar between the two groups. The proportion of muscle fibre exhibiting a diameter inferior to $20 \mu \mathrm{m}$ (indicating hyperplasia) was very low $(<0.5 \%)$ and did not differ between the two groups. The total muscle fibre number per myotome was significantly $(p<0.05)$ higher (+22\%) for the HY group compared to the LY group (Table 3).

\subsubsection{Flesh quality assessment}

Colour measurements (Table 4) showed that the fillet luminosity of the HY group was significantly higher than that of the LY group $(p<0.001)$. No difference was observed between the two groups for the redness and yellowness parameters.

Muscle pH measured 48h after death was not different between the two groups (Table 4).

Fat content of the Norwegian Quality Cut was significantly higher (+0.8 lipid point value; $\mathrm{p}<0.05$ ) in the HY group than in the LY group (Table 4).

Mechanical resistance of the raw fillet was significantly higher in the caudal part of the fillet for the HY group than for the LY group $(p<0.01)$ but no significant difference was observed in the anterior part of the fillet (Table 5). For the cooked fillet, both samples (anterior and caudal) presented significantly higher mechanical resistance $(p<0.01$ and $\mathrm{p}<0.05$ respectively) in the LY group compared to the HY group.

The salting and smoking yields of the HY and LY groups were not different and the total losses of this two steps represented 6\% of the initial fillet weight (Table 6).

Sensory evaluation did not show great difference between the two groups. After cooking, only the flavour of cooked potato, a characteristic classically detected in cooked fish, was slightly more intense $(p<0.01)$ in HY (Figure 2). After smoking (Figure 3), the main differences observed between the two groups concerned the appearance of the cutlet. Evaluation of the internal surface of the cutlet revealed a tendency for the LY group to have a more intense orange colour $(p<0.1)$, and a less visible white stria (myosepta) also for the LY group $(p<0.01)$. Examination of the external surface the fillet revealed that fillets from LY group were significantly darker $(p<0.05)$.

\section{Discussion}

\subsubsection{Determinism of the yields}

Raw fillet yield of the two groups differed by $16 \%$, which was a big difference compared with previous studies in this area. For example, previous works report a $6 \%$ difference comparing rainbow trout strains (Smith et al. 1988) or a $7 \%$ difference for fed and starved Atlantic salmon (Einen et al. 1998). Moreover, our model allowed a comparison between fish with low and high muscle mass from the same rearing conditions, avoiding genetic or environmental effects on fillet yield. In addition, the use of sterile all female triploid fish avoided potential sex and/or sexual maturation effects. So we obtained two groups of fish from the same origin, presenting the same overall growth, but differing essentially in fillet yield.

The mean fillet yield (means of HY and LY groups) obtained in our experiment was 61\% and $41 \%$ for untrimmed and trimmed fillets respectively. Thus, the filleting process accounted on average for $39 \%$ of the filleting loss and the trimming process $20 \%$. The total filleting and trimming loss (mean of 59\%) was rather great compared to other studies in rainbow trout (de Francesco et al. 2004; Rasmussen and Ostenfeld 2000); the higher carcass yield (c. 90\%) observed in these studies probably contributes to the lower total loss observed. These losses were also greater than that observed on other salmonid species like Atlantic salmon, which present weight loss due to filleting and trimming 
ranging from 30 to $45 \%$ (Morkore et al. 2001). Large rainbow trout present a higher viscero-somatic index and also a higher peripheral fat deposit than Atlantic salmon (Morkore et al. 2002; Morkore 2002). Both visceral fat and peripheral adipose tissue contributed to the lower fillet yield obtained in rainbow trout compared to Atlantic salmon. In our experiment, the lower visceral index obtained in the HY group showed that, the higher fillet yield observed was associated with a higher muscle growth than visceral adipose tissue one. The trimmed and skinned fillet yields were also significantly higher for the HY than the LY group: the trimming process did not modify the difference in yield observed on the raw fillet between the two groups. To sum up, the weight of tissue eliminated during this process was proportionally the same between the two groups. The quantification of cutlet tissue area with the colour image analysis system confirmed that peripheral fat tissue content was similar between the two groups in proportion but higher in total area for the HY group compared to the LY group. Accordingly the HY group did not present higher muscle/peripheral adipose tissue ratio, and thus the increase in muscle mass was associated with an equivalent increase in peripheral adipose tissue.

In our study, fillet weight losses due to salting and smoking processes were not different between the two groups. Smoking loss was shown to depend on fillet fat content: lean fillet, with high water content, leading to higher salting loss than fatty fish (Cardinal et al. 2001; Morkore et al. 2001). In our experiment, the difference in fillet fat content (0.8 units) between the two groups was probably too small to induce an effect on salting and smoking losses.

\subsubsection{Muscle growth}

The post-hatching muscle growth of fish species reaching high body weight, like salmonids, is achieved by both an increase in muscle fibre length and diameter (hypertrophy) and increase in muscle fibre number (hyperplasia) (Weatherley et al. 1988). In our experiment, the proportion of small fibres (diameter $<20 \mu \mathrm{m}$ ) was very low, indicating that hyperplasia does not contribute so much to muscle growth (Weatherley et al. 1988). It is considered that above $44 \%$ of the fish maximal ultimate size (corresponding to $50 \mathrm{~cm}$ fork length for rainbow trout), muscle growth was achieved mainly by hypertrophy (Weatherley et al. 1988). In our study, fish were around $60 \%$ of their theoretic ultimate size which could explain both the high proportion of muscle fibre with a large diameter $(>180 \mu \mathrm{m})$ and the low content of small diameter fibre. However, more than $90 \%$ of the fibres had not reached their maximal diameter showing a still remaining overall and muscle growth potential as observed on bigger rainbow trout $(6 \mathrm{~kg})$ that present a mean fibre diameter of $180 \mu \mathrm{m}$ (Poontawee et al. 2007). Because of the same muscle mean fibre size observed between the two groups, we can assume that the higher muscle mass obtained in the HY group was not the result of a higher hypertrophy process of muscle fibres. Such a mechanism of muscle fibre hypertrophy was observed for example in selected chicken line for breast muscle yield (Guernec et al. 2003), in pork with Halothane gene (Lefaucheur and Gerrard 1998) or in callipyge sheep (Carpenter et al. 1996). In our experiment, the higher muscle fibre number observed on the HY group compared to the LY, indicate a higher hyperplasia of muscle fibre that led to a higher muscle mass. Such a mechanism was observed on double muscle cattle during the prenatal muscle growth, (for review see (Rehfeldt et al. 2000). Due to the big difference in fibre number $(+76,000$ fibres, $+22 \%$ per myotome in HY group compare to LY) between the two groups and the similar muscle fibre size distribution (data not shown), we can suppose that hyperplasia was higher all along the growth phase of the HY group. Indeed, this difference could not be the result of a higher hyperplasia during the early development period, because the total muscle fibre number of rainbow trout fry was, for example, only 2500 fibres per cross-sectional area at hatching (Valente et al. 1999). In our study, the phenotypic variability in muscle mass was used to obtain the two groups. The genetic variability and heritability of muscle fibre number are rather high in land species (Rehfeldt et al. 2000) 
and seems also to be important in Atlantic salmon $\left(h^{2}=0.33\right)$ (Vieira et al. 2007). The muscle fibre number was probably under the control of different genes and also affected by non-genetic environmental factors and/or environment-genotype interactions (Johnston 2006). The understanding of the muscle fibre hyperplasia mechanism is an important goal for future investigations and for fish breeders with a direct interest in fish farming in term of product yield.

To our knowledge, this paper reports for the first time a relationship between the muscle cellularity and different fillet yield in a fish species.

\subsubsection{Flesh quality}

The higher muscle mass in the HY group was associated with both a higher subcutaneous adipose tissue and fillet lipid content than in the LY group. Such a result was the opposite to that observed for land species, for example pig or cattle with higher muscle mass have a lower muscle fat content (Hocquette et al. 2000). The increase in fillet yield we observed was thus the result of both higher muscle and adipose tissue development in the fillet in the HY group compared to the LY group, which deposited a rather higher quantity of fat in the perivisceral adipose tissue. In rainbow trout a negative genetic correlation between visceral fat deposition and flesh fat content has been published (from -0.33 to -0.43 ) (Gjerde and Schaeffer 1989; Kause et al. 2002). Such correlations lead to a balance between the two main sites (visceral and muscle) of fat deposition in salmonids (Quillet et al. 2005), and are also in accordance with the positive genetic correlation observed between carcass or fillet yields and flesh fat content (Gjerde and Schaeffer 1989; Kause et al. 2002). Finally the higher fillet yield observed in the HY group was the result of both a higher muscle growth and a different fat tissue allocation compared to the LY group.

Flesh colour is an important quality criterion in salmonids. The luminosity $\left(L^{\star}\right)$ of the raw flesh was higher in the HY group compared to the LY group, but no difference was observed on the chromatic components. This difference can be explained by the higher muscle fat content measured for fish from the HY group. A relationship between raw flesh cutlet luminosity and fat content has therefore already been observed in salmonid species (Marty-Mahe et al. 2004; Morkore et al. 2001). The difference in luminosity between the two groups could also be explained by a different structure of the muscle tissue. In our study, the HY fishes present a higher myosepta area than the LY group. The myosepta is the whiter tissue in the trout flesh, and so, probably contribute to the overall luminosity of the fillet.

The instrumental evaluation of flesh texture shows that, for raw flesh, the mechanical resistance of the caudal part was higher than this of the anterior part of the fillet. On cooked flesh the opposite result was obtained, as already observed in salmon (Morkore et al. 2002). In salmonids, the mechanical resistance change due to heating was different among the fillet sections (Morkore et al. 2002). The mechanical resistance, measured in the caudal part of the raw fillet of the HY fish, was higher than in the LY group. In cooked flesh resistance was higher in LY fish in both parts of the fillet. The determinism of the mechanical resistance of raw flesh is rather complex and depends on collagen cross-link content like pyridinoline (Li et al. 2005), muscle fibre size (Bugeon et al. 2003), pH (Dunajski 1979) and lipid content (Thakur et al. 2002). In our experiment, both groups presented a similar muscle fibre size and $\mathrm{pH}$ and the higher fat content of the HY group would have led to a softer flesh. From our data, we could not state an influence of these characteristics on raw flesh mechanical resistance, and we have no data about the content or characteristics of collagen. On cooked flesh, an inverse relationship is observed between flesh firmness and muscle fibre size or collagen content comparing different fish species (Hatae et al. 1986; Hurling et al. 1996). However, such a relationship was not demonstrated on cooked flesh from fish within the same species. The collagen content of the caudal part was higher than the anterior part of the fillet (Montero and Borderias 1989). The decrease in mechanical resistance of the caudal part after cooking 
could be explained by the collagen thermo-solubilisation and gelatinization as observed in fish muscle (Lampila 1990; Sikorski et al. 1984). Accordingly, we can assume that higher collagen content could be present in the HY group, explaining both the higher mechanical resistance of the raw fillet in the caudal part and the lower resistance of the cooked flesh in the caudal and anterior part. All these findings suggest that further studies are needed to investigate the relationship between muscle mass and the content and characteristics of connective tissue. No difference in texture was observed by the sensory panel, so the differences measured instrumentally were probably too slight on the cooked flesh to be detected by a sensory panel.

Sensory evaluation of smoked fillet detected some differences, especially on fillet structure with more "white stria" in the HY group than in the LY. This result can be related to the same significant difference in myosepta area measured by computer vision analysis on the crude product. Myosepta are sheets of connective tissue connecting myomeres and contains mainly collagen and lipid due to the presence of many adipocytes (Zhou et al. 1995). A positive relationship between area of myosepta and flesh lipid content was observed (Borderias et al. 1999; Marty-Mahe et al. 2004). For a sensory panel, such a criteria was also associated with fatty flesh, but a possible relationship with collagen content could also be suspected (Borderias et al. 1999), as the lipid difference between the two groups was weak (0.8 unit) in our experiment. Finally, the differences in fillet appearance can be related to the structure of the fillets in each group, especially to the connective tissue distribution. The difference in myosepta area was only observed on the smoked products by the sensory panel. On the cooked flesh, the thermo-solubilization of connective tissue and modification of flesh colour and structure did not allow the detection of any differences between the two groups. Finally the consequences of the different muscle masses observed between the two groups were rather low in rainbow trout flesh quality perceived by a sensory panel and concerned principally the fillet appearance of the smoked fillet.

\section{Conclusions}

In large rainbow trout, the different muscle mass observed in our study between the two groups was associated to an increase in muscle fibre number without modification of muscle fibre size at the commercial size analysed. Higher muscle mass was also associated with a slightly higher muscle fat content and raw flesh luminosity, a higher mechanical resistance for the raw flesh but a softer cooked flesh. The impact of a higher fillet yield on flesh quality was rather limited; the appearance of the raw and smoked fillet was however affected and associated to a higher area of myosepta for fish with the higher fillet yield.

\section{Acknowledgments}

This work was supported by a grant $\left(\mathrm{N}^{\circ} 076 / 04 / \mathrm{C}\right)$ from the OFIMER, IFOP and CIPA. The authors thank Josiane Cornet, Camille Knockaert from IFREMER, Gilles Paboeuf, Thierry Kerneis, Vincent Gayet from INRA and Mireille Cambert from CEMAGREF for their technical assistance. 


\section{References}

BORDERIAS, A. J., GOMEZ-GUILLEN, M. C., HURTADO, O., and MONTERO, P. 1999. Use of image analysis to determine fat and connective tissue in salmon muscle. Eur. Food Res. Technol. 209, 104-107.

BUGEON, J., LEFEVRE, F., and FAUCONNEAU, B. 2003. Fillet texture and muscle structure in brown trout (Salmo trutta) subjected to long-term exercise. Aquac Res 34, 1287-1295.

CARDINAL, M., KNOCKAERT, C., TORRISSEN, O., SIGURGISLADOTTIR, S., MORKORE, T., THOMASSEN, M., and LUC VALLET, J. 2001. Relation of smoking parameters to the yield, colour and sensory quality of smoked Atlantic salmon (Salmo salar). Food Res Int 34, 537-550.

CARPENTER, E., RICE, O. D., COCKETT, N. E., and SNOWDER, G. D. 1996. Histology and composition of muscles from normal and callipyge lambs. J. Anim. Sci. 74, 388-393.

CIE. 1976. Official recommendations on uniform colour space, colour difference equations and metric colour terms. Commission Internationale de l'Eclairage 15. Paris, France.

DE FRANCESCO, M., PARISI, G., MEDALE, F., LUPI, P., KAUSHIK, S. J., and POLI, B. M. 2004. Effect of long-term feeding with a plant protein mixture based diet on growth and body/fillet quality traits of large rainbow trout (Oncorhynchus mykiss). Aquaculture 236, 413-429.

DUNAJSKI, E. 1979. Texture of fish muscle. J. Text. Stud. 10, 301-318.

EINEN, O., MORKORE, T., RORA, A. M. B., and THOMASSEN, M. S. 1999. Feed ration prior to slaughter--a potential tool for managing product quality of Atlantic salmon (Salmo salar). Aquaculture 178, 149-169.

EINEN, O., WAAGAN, B., and THOMASSEN, M. S. 1998. Starvation prior to slaughter in Atlantic salmon (Salmo salar): I. Effects on weight loss, body shape, slaughter- and filletyield, proximate and fatty acid composition. Aquaculture 166, 85-104.

FAUCONNEAU, B., ALAMI-DURANTE, H., LAROCHE, M., MARCEL, J., and VALLOT, D. 1995. Growth and meat quality relations in carp. Aquaculture 129, 265-297.

GJERDE, B. and SCHAEFFER, L. R. 1989. Body traits in rainbow trout : II. Estimates of heritabilities and of phenotypic and genetic correlations. Aquaculture 80, 25-44.

GUERNEC, A., BERRI, C., CHEVALIER, B., WACRENIER-CERE, N., BIHAN-DUVAL, E., and DUCLOS, M. J. 2003. Muscle development, insulin-like growth factor-I and myostatin mRNA levels in chickens selected for increased breast muscle yield. Growth Horm IGF Res 13, 8-18.

hATAE, K., TOBIMATSU, A., TAKEYAMA, M., and MATSUMOTO, J. J. 1986. Contribution of connective tissues on the texture difference of various fish species. Bull. Jpn. Soc. Sci. Fish. 52, 2001-2007.

HOCQUETTE, J., ORTIGUES-MARTY, I., DAMON, M., HERPIN, P., and GEAY, Y. 2000. Energy metabolism in skeletal muscle of meat-producing animals. Prod. Anim. 13.

HURLING, R., RODELL, J. B., and HUNT, H. D. 1996. Fiber diameter and fish texture. J. Text. Stud. 27, 679-685.

JOHNSTON, I. A. 2006. Environment and plasticity of myogenesis in teleost fish. J. Exp. Biol. 209, 2249-2264.

JOHNSTON, I. A., ABERCROMBY, M., VIEIRA, V. L., SIGURSTEINDOTTIR, R. J., KRISTJANSSON, B. K., SIBTHORPE, D., and SKULASON, S. 2004. Rapid evolution of muscle fibre number in post-glacial populations of Arctic charr Salvelinus alpinus. J. Exp. Biol. 207, 4343-4360.

JOHNSTON, I. A., ALDERSON, R., SANDHAM, C., DINGWALL, A., MITCHELL, D., SELKIRK, C., NICKELL, D., BAKER, R., ROBERTSON, B., WHYTE, D., and SPRINGATE, J. 2000a. Muscle fibre density in relation to the colour and texture of smoked Atlantic salmon (Salmo salar L.). Aquaculture 189, 335-349. 
JOHNSTON, I. A., ALDERSON, R., SANDHAM, C., MITCHELL, D., SELKIRK, C., DINGWALL, A., NICKELL, D., BAKER, R., ROBERTSON, B., WHYTE, D., and SPRINGATE, J. 2000b. Patterns of muscle growth in early and late maturing populations of Atlantic salmon (Salmo salar L.). Aquaculture 189, 307-333.

KAUSE, A., PAANANEN, T., RITOLA, O., and KOSKINEN, H. 2007. Direct and indirect selection of visceral lipid weight, fillet weight and fillet percent in a rainbow trout breeding program. J. Anim. Sci. 85, 3218-3227.

KAUSE, A., RITOLA, O., PAANANEN, T., MANTYSAARI, E., and ESKELINEN, U. 2002. Coupling body weight and its composition: a quantitative genetic analysis in rainbow trout. Aquaculture 211, 65-79.

LAMPILA, L. E. 1990. Comparative microstructure of red meat, poultry anf fish muscle. J. Muscle Foods 1, 247-267.

LEFAUCHEUR, L. and GERRARD, D. 1998. Muscle fiber plasticity in farm mammals. Proceedings of the American Society of Animal science 1-19.

LI, X. J., BICKERDIKE, R., LINDSAY, E., CAMPBELL, P., NICKELL, D., DINGWALL, A., and JOHNSTON, I. A. 2005. Hydroxylysyl pyridinoline cross-link concentration affects the textural properties of fresh and smoked Atlantic salmon (Salmo salar L.) flesh. J. Agric. Food Chem. 53, 6844-6850.

LOPEZ-DE-LEON, A. and ROJKIND, M. 1985. A simple micromethod for collagen and total protein determination in formalin-fixed paraffin-embedded sections. J. Histochem. Cytochem. 33, 737-743.

MARTY-MAHE, P., LOISEL, P., FAUCONNEAU, B., HAFFRAY, P., BROSSARD, D., and DAVENEL, A. 2004. Quality traits of brown trouts (Salmo trutta) cutlets described by automated color image analysis. Aquaculture 232, 225-240.

MONTERO, P. and BORDERIAS, J. 1989. Distribution and hardness of muscle connective tissue in hake (Merluccius merluccius L.) and trout (Salmo irideus Gibb). Z. Lebensm. Unters. Forsch. 189, 530-533.

MORKORE, T. 2002. Texture, fat content and product yield of salmonids. Doctor Scientiarum Theses Agricultural University of Norway, $146 \mathrm{pp}$.

MORKORE, T., HANSEN, A. A., UNANDER, E., and EINEN, O. 2002. Composition, liquid leakage, and mechanical properties of farmed rainbow trout: Variation between fillet sections and the impact of ice and frozen storage. J. Food Sci. 67, 1933-1938.

MORKORE, T., VALLET, J. L., CARDINAL, M., MONTERO, R., TORRISSEN, O. J., NORTVEDT, R., SIGURGISLADOTTIR, S., and THOMASSEN, M. S. 2001. Fat content and fillet shape of Atlantic salmon: Relevance for processing yield and quality of raw and smoked products. J. Food Sci. 66, 1348-1354.

PAAVER, T., GROSS, R., and ILVES, P. 2004. Growth Rate, Maturation Level and Flesh Quality of Three Strains of Large Rainbow Trout (Oncorhynchus mykiss) Reared in Estonia. Aquacult Int 12, 33-45.

POONTAWEE, K., WERNER, C., MULLER-BELECKE, A., HORSTGEN-SCHWARK, G., and WICKE, M. 2007. Flesh qualities and muscle fiber characteristics in triploid and diploid rainbow trout. J Appl Ichthyol 23, 273-275.

QUILLET, E., LE GUILLOU, S., AUBIN, J., and FAUCONNEAU, B. 2005. Two-way selection for muscle lipid content in pan-size rainbow trout (Oncorhynchus mykiss). Aquaculture 245, 49-61.

RASMUSSEN, R. S. 2001. Quality of farmed salmonids with emphasis on proximate composition, yield and sensory characteristics. Aquac Res 32, 767-786.

RASMUSSEN, R. S. and OSTENFELD, T. H. 2000. Effect of growth rate on quality traits and feed utilisation of rainbow trout (Oncorhynchus mykiss) and brook trout (Salvelinus fontinalis). Aquaculture 184, 327-337.

REHFELDT, C., FIEDLER, I., DIETL, G., and ENDER, K. 2000. Myogenesis and postnatal skeletal muscle cell growth as influenced by selection. Livest Prod Sci 66, 177-188. 
RORA, A. M. B., MORKORE, T., and EINEN, O. 2001. Primary processing (Evisceration and filleting). In Farmed Fish Quality,(S.C. Kestin and P.D. Warriss, eds.) pp. 249-260, Blackwell Science, Oxford.

SIKORSKI, Z. E., SCOTT, D. N., and BUISSON, D. H. 1984. The role of collagen in the quality and processing of fish. Crit. Rev. Food Sci. Nutr. 20, 301-343.

SMITH, R., KINCAID, H., REGENSTEIN, J., and RUMSEY, G. 1988. Growth, carcass composition, and taste of rainbow trout of different strains fed diets containing primarily plant or animal protein. Aquaculture 70, 309-321.

SZCZESNIACK, A. S., HUMAUGH, P. R., and BLOCK, H. W. 1970. Behaviour of different foods in the standard shear compression cell of the shear press and the effect of sample weight on peak area and maximum force. J. Text. Stud. 1, 356-378.

THAKUR, D. P., MORIOKA, K., ITOH, Y., and OBATAKE, A. 2002. Influence of muscle biochemical constituents on the meat texture of cultured yellowtail (Seriola quinqueradiata) at different anatomical locations. J. Sci. Food. Agric. 82, 1541-1550.

TOUSSAINT, C. A., MÉDALE, F., DAVENEL, A., FAUCONNEAU, B., HAFFRAY, P., and AKOKA, S. 2002. Determination of the lipid content in fish muscle by a self-calibrated NMR relaxometry method: comparison with classical chemical extraction methods. J. Sci. Food. Agric. 82, 173-178.

VALENTE, L. M. P., ROCHA, E., GOMES, E. F. S., SILVA, M. W., OlIVEIRA, M. H., MONTEIRO, R. A. F., and FAUCONNEAU, B. 1999. Growth dynamics of white and red muscle fibres in fast- and slow-growing strains of rainbow trout. J. Fish Biol. 55, 675-691.

VIEIRA, V. L. A., NORRIS, A., and JOHNSTON, I. A. 2007. Heritability of fibre number and size parameters and their genetic relationship to flesh quality traits in Atlantic salmon (Salmo salar L.). Aquaculture 272, S100-S109.

WEATHERLEY, A. H., GILL, H. S., and LOBO, A. F. 1988. Recruitment and maximal diameter of axial muscle fibres in teleosts and their relationship to somatic growth and ultimate size. J. Fish Biol. 33, 851-859.

ZHOU, S., ACKMAN, R. G., and MORISSON, C. 1995. Storage of lipids in the myosepta of atlantic salmon (Salmo salar). Fish Physiol. Biochem. 14, 171-178.

\section{Tables}

Table 1.

sensory descriptors used for cooked and smoked flesh

\begin{tabular}{|c|c|c|}
\hline Descriptors & Cooked flesh & Smoked flesh \\
\hline \multirow{4}{*}{ Odour } & Global intensity & Global intensity \\
& Fat fish & Wood fire \\
& Milky & Cold ashes \\
& Cooked potato & Fat fish \\
& Earthy & Raw fish-like \\
& & Herring-like \\
& Amine \\
\hline \multirow{4}{*}{ Appearance } & Orange colour & Internal surface: \\
& Density of the flesh & Orange colour \\
& Fat droplets in gravy & Pink colour \\
& & Colour homogeneity \\
& & Fat droplets \\
& & Size of white stria \\
& & External surface : \\
& & Darkness \\
\hline
\end{tabular}




\begin{tabular}{|c|c|c|}
\hline \multirow{4}{*}{ Flavour } & Global intensity & Global intensity \\
& Fat fish & Wood fire \\
& Cooked potato & Cold ashes \\
& Eaw fish-like \\
& Earthy & Herring-like \\
& Betallic taste & Salty \\
& & Amine \\
\hline \multirow{4}{*}{ Texture } & Firmness & Firmness \\
& Fracturability & Crunchy \\
& Exudation & Melting texture \\
& Perception of fibres & Fatty \\
& Humidity & Pasty \\
& Pasty texture & \\
& Sticky texture & \\
& Fatty film on tongue & \\
\hline
\end{tabular}

Table 2.

Weight and processing yields of rainbow trout presenting low (LY) or high (HY) fillet yield. Mean \pm Standard Deviation, $\mathrm{n}=25$.

\begin{tabular}{|c|c|c|c|}
\hline Parameters & $\overline{L Y}$ & $\mathrm{HY}$ & Significance level (ANOVA) \\
\hline Body weight (g) & $3543 \pm 461$ & $3655 \pm 394$ & NS \\
\hline Body length (mm) & $592 \pm 24$ & $616 \pm 18$ & $p<0.001$ \\
\hline $\mathrm{K}\left(\mathrm{g} \cdot \mathrm{mm}^{-3} \cdot 10^{5}\right)$ & $1.71 \pm 0.14$ & $1.56 \pm 0.15$ & $p<0.001$ \\
\hline VSI (\%) & $24.1 \pm 3.8$ & $13 \pm 1.8$ & $p<0.001$ \\
\hline Carcass yield (\%) & $74.7 \pm 3.8$ & $85.8 \pm 1.8$ & $p<0.001$ \\
\hline Raw fillet yield (\%) & $56.2 \pm 3.2$ & $65.4 \pm 1.4$ & $p<0.001$ \\
\hline Fillet Yield* (\%) & $36.8 \pm 3.0$ & $44.4 \pm 1.6$ & $p<0.001$ \\
\hline
\end{tabular}

NS: Not Significant, * Trimmed and skinned fillet.

Table 3.

Macroscopic and microscopic characteristics of muscle of rainbow trout presenting low (LY) or high (HY) fillet yield. Mean \pm Standard Deviation, $\mathrm{n}=15$.

\begin{tabular}{cccc}
\hline Parameters & $\mathrm{LY}$ & $\mathrm{HY}$ & Significance level (ANOVA) \\
\hline Total cutlet area $\left(\mathrm{mm}^{2}\right)$ & $3465 \pm 541$ & $4175 \pm 411$ & $\mathrm{p}<0.001$ \\
Adipose tissue area $\left(\mathrm{mm}^{2}\right)$ & $953 \pm 218$ & $1179 \pm 202$ & $\mathrm{P}<0.01$ \\
Adipose tissue area $(\%)$ & $27.2 \pm 2.6$ & $28.0 \pm 3.0$ & $\mathrm{NS}$ \\
Myosepta area $(\%)$ & $11.3 \pm 1.1$ & $12.4 \pm 0.8$ & $\mathrm{p}<0.01$ \\
Mean Fibre diameter $(\mu \mathrm{m})$ & $116 \pm 16$ & $113 \pm 14$ & $\mathrm{NS}$ \\
Fibre diameter $<20 \mu \mathrm{m}(\%)$ & $0.35 \pm 0.36$ & $0.17 \pm 0.26$ & $\mathrm{NS}$ \\
Total number of fibres $\left(\mathrm{x} 10^{3}\right)$ & $343 \pm 86$ & $419 \pm 10$ & $\mathrm{p}<0.05$ \\
\hline
\end{tabular}

NS: Not Significant. 
Table 4.

Flesh colour, pH and lipid content of rainbow trout with low (LY) or high (HY) fillet yield. Mean \pm Standard Deviation, $n=15$, except for fat content $n=25$.

\begin{tabular}{cccc}
\hline Parameters & $\mathrm{LY}$ & $\mathrm{HY}$ & Significance level (ANOVA) \\
\hline $\mathrm{L}^{*}$ & $43.5 \pm 1.6$ & $46.1 \pm 2.0$ & $\mathrm{p}<0.001$ \\
$\mathrm{a}^{*}$ & $13.8 \pm 1.0$ & $13.3 \pm 0.7$ & $\mathrm{NS}$ \\
$\mathrm{b}^{*}$ & $18.3 \pm 1.4$ & $18.1 \pm 0.9$ & $\mathrm{NS}$ \\
$\mathrm{pH}$ 48h post mortem & $6.40 \pm 0.07$ & $6.39 \pm 0.05$ & $\mathrm{NS}$ \\
Fat content (g/100 g fresh & $8.3 \pm 1.4$ & $9.1 \pm 1.6$ & $\mathrm{p}<0.05$ \\
muscle) & & & \\
\hline
\end{tabular}

NS: Not Significant.

Table 5.

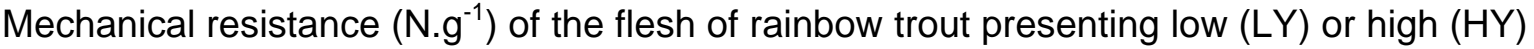
fillet yield. Mean \pm Standard Deviation, $n=15$.

\begin{tabular}{ccccc}
\hline Products & Measurement: & $\mathrm{LY}$ & $\mathrm{HY}$ & Significance level (ANOVA) \\
\hline \multirow{2}{*}{ Raw flesh } & caudal part & $33.1 \pm 4.6$ & $39.2 \pm 6.0$ & $\mathrm{p}<0.01$ \\
& anterior part & $7.4 \pm 0.9$ & $6.7 \pm 1.0$ & $\mathrm{NS}$ \\
\hline Cooked & caudal part & $19.2 \pm 4.6$ & $15.1 \pm 3.3$ & $\mathrm{p}<0.01$ \\
flesh & anterior part & $22.0 \pm 4.8$ & $17.9 \pm 3.7$ & $\mathrm{p}<0.05$ \\
\hline
\end{tabular}

NS: Not-Significant.

Table 6.

Salting and smoking losses of fillet from rainbow trout presenting low (LY) or high (HY) fillet yield. Mean \pm Standard Deviation, $n=10$.

\begin{tabular}{cccc}
\hline Parameters & LY & HY & Significance level (ANOVA) \\
\hline Salting loss (\%) & $2.2 \pm 1.0$ & $2.4 \pm 0.4$ & NS \\
Smoking loss (\%) & $4.0 \pm 0.6$ & $4.0 \pm 0.9$ & NS \\
Total loss (\%) & $6.2 \pm 1.3$ & $6.5 \pm 1.1$ & NS \\
\hline
\end{tabular}

NS: Not Significant. 


\section{Figures}

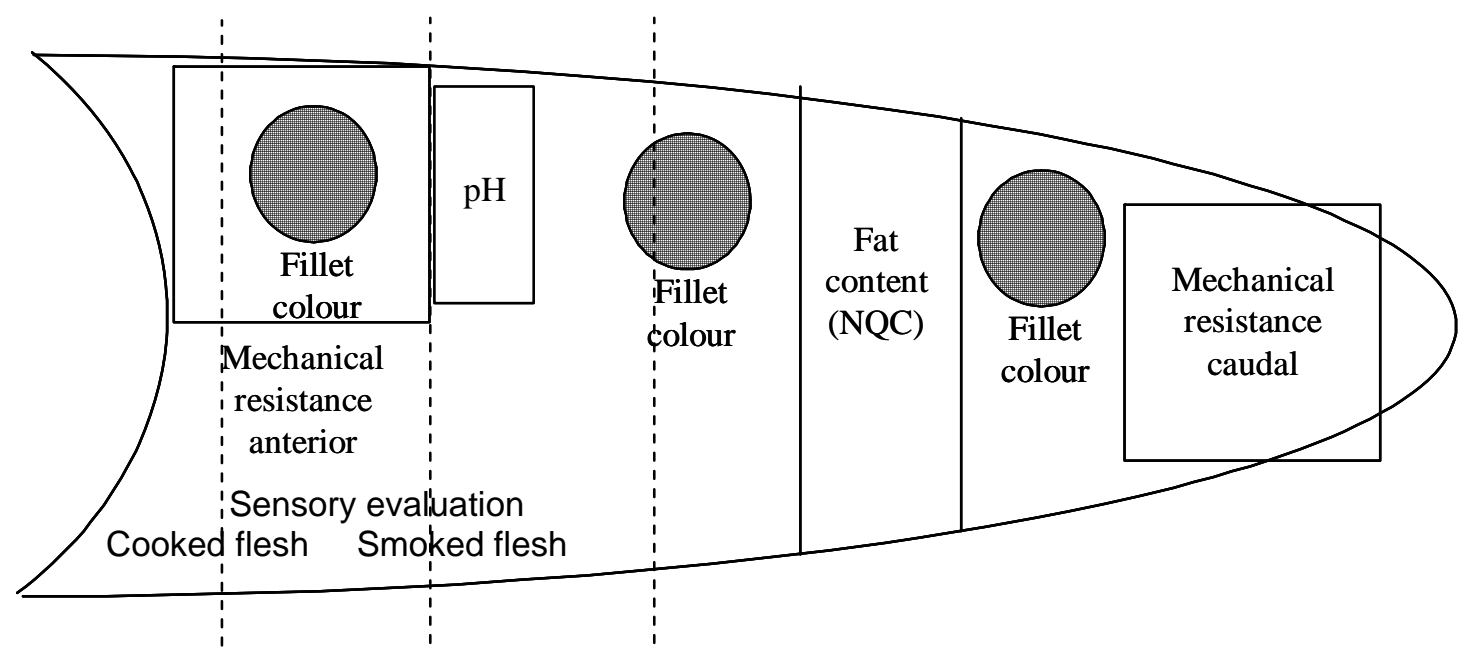

Figure 1: Schematic description of sampling sites for analysis of flesh quality. 


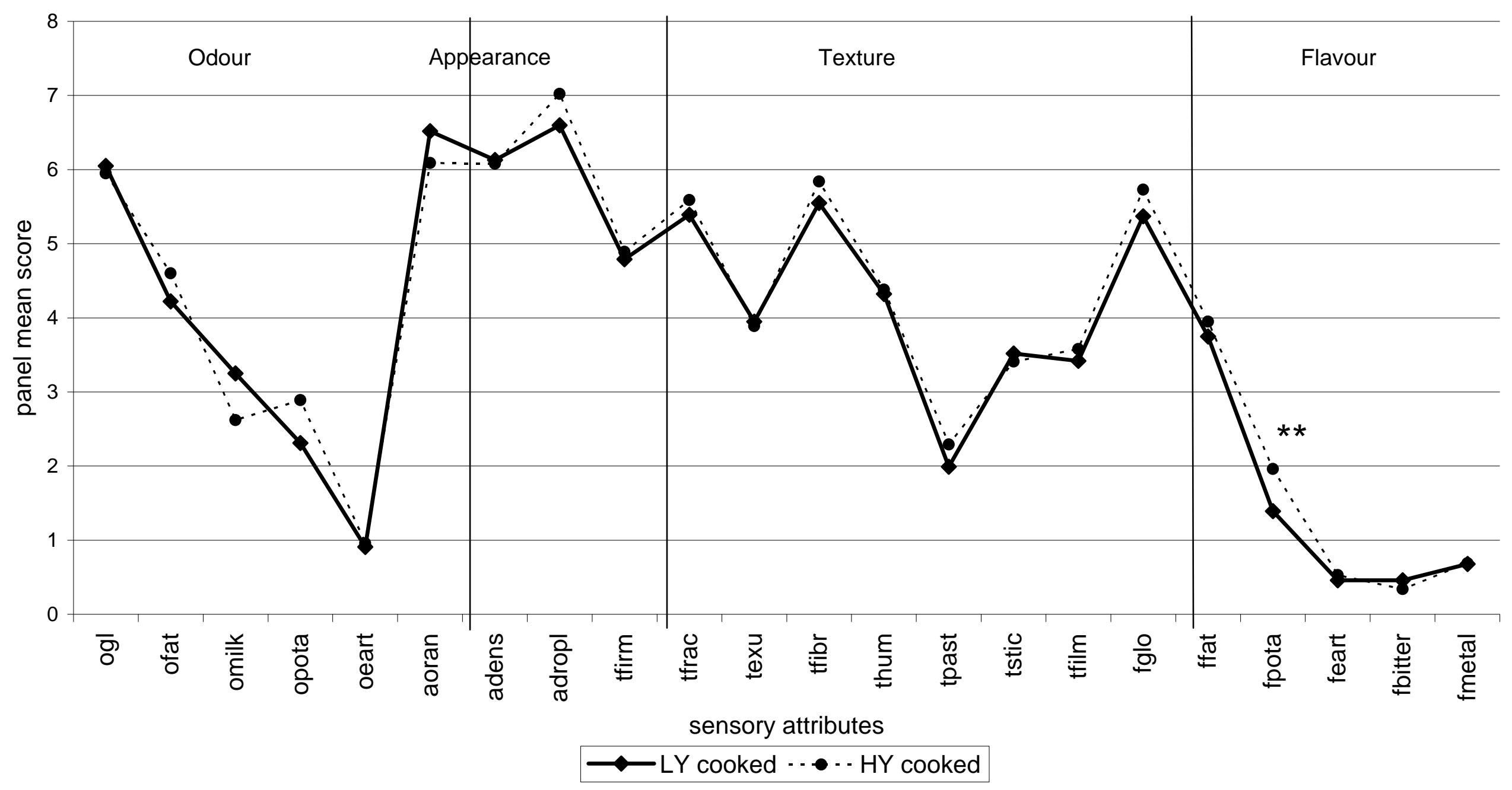

Figure 2.

Sensory characteristics of the cooked flesh of rainbow trout presenting low (LY) or high (HY) fillet yield. Sensory attributes were : odour: global intensity (oglo), fat fish (ofat), milky (omilk), potato (opota), earthy (oeart); appearance: orange colour (aoran), density of the flesh (adens), fat droplets in gravy (adropl); texture: firmness (tfirm), fracturability (tfrac), exudation (texu), perception of fibres (tfibr), humidity (thum), pasty texture (tpast), sticky texture (tstic), fatty film on tongue (tfat); flavour: global intensity (fglo), fat fish (ffat), potato (fpota), earthy (feart), bitter (fbitter), metallic taste (fmetal). ${ }^{*}=p<0.05 ; * *=0.01$. 


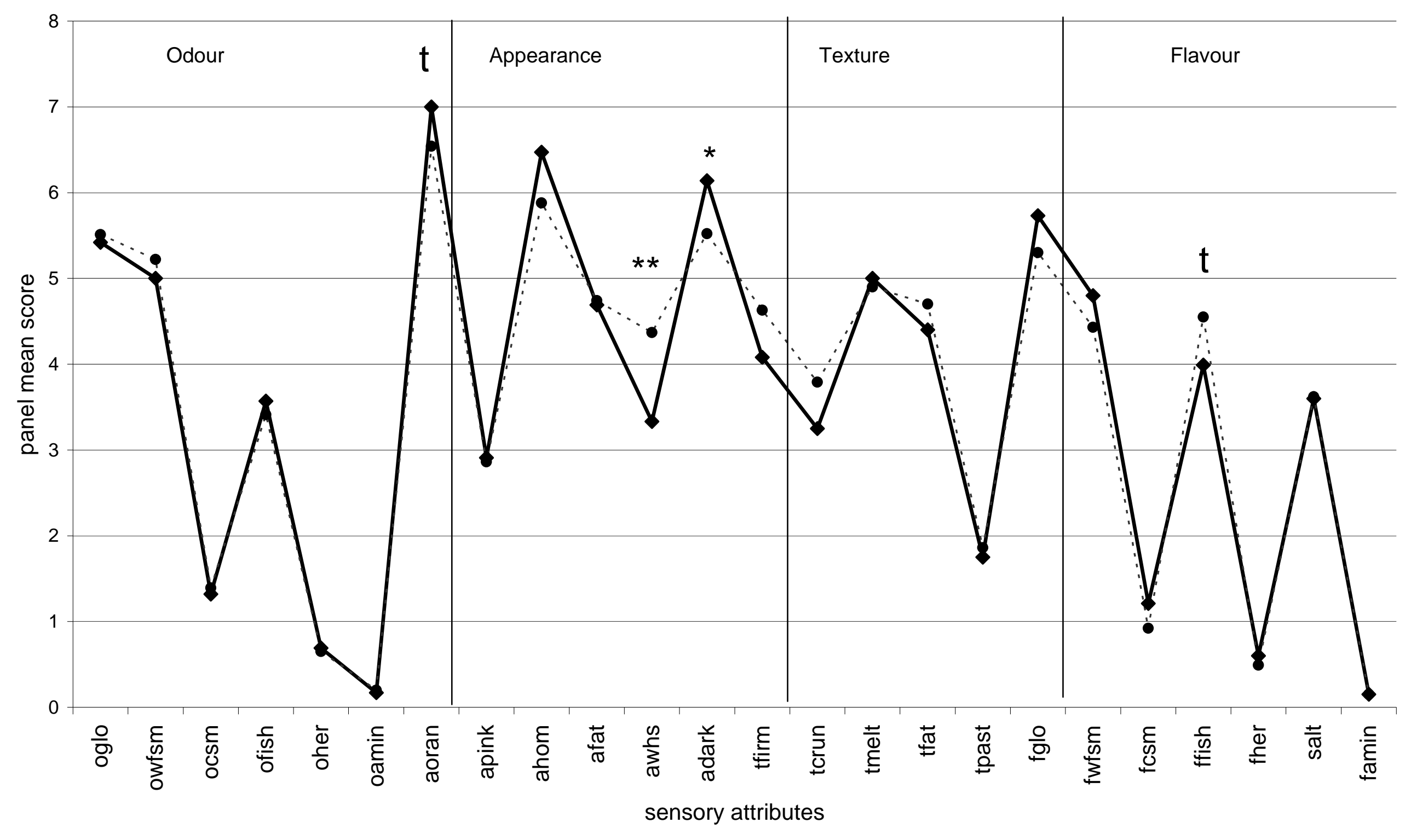

$\neg$ LY smoked - - - HY smoked 
Figure 3.

Sensory characteristics of the smoked flesh of rainbow trout presenting low (LY) or high (HY) fillet yield. Sensory attributes were : odour: global intensity (oglo), wood fire (owfsm), cold ashes (ocsm), raw fish-like (ofish), herring-like (oher), amine (oamin); appearance of the internal surface of the cutlet: orange colour (aoran), pink colour (apink), colour homogeneity (ahom), fat droplets (afat), size of the white stria (awhs), appearance of the external surface of the cutlet: darkness (adark); texture: firmness (tfirm), crunchy (tcrun), melting texture (tmelt), fatty (tfat), pasty texture (tpast); flavour: global intensity (fglo), wood fire (fwfsm), cold ashes (fcsm), raw fish-like (ffish), herring-like (fhr), salty (salt) and amine (famin). $t=0.05<p<0.10 ; *=p<0.05 ; * \star ~=p<0.01$. 
